\title{
Influence of feed form and corn particle size on nutrient digestibility and energy utilization by young turkeys
}

\section{André Favero ${ }^{1}$, Alex Maiorka ${ }^{1}$, Ana Vitória Fischer da Silva ${ }^{2}$, Fabio Luiz de Paula Valle ${ }^{1}$, Samuel Augusto dos Santos ${ }^{1}$, Keysuke Muramatsu ${ }^{3}$}

\footnotetext{
1 Departamento de Ciências Veterinárias - Universidade Federal do Paraná, Curitiba.

2 Departmento de Fisiologia - Universidade Federal do Paraná, Curitiba.

${ }^{3}$ BRF - Brasil Foods S/A , Videira, Santa Catarina.
}

\begin{abstract}
A digestibility trial with 16 to 21-day-old turkeys was conducted to study the effects of feed form and corn particle size on the coefficient of total intestinal tract apparent digestibility of dry matter (DM), nitrogen (N), ether extract (EE), aparent metabolizable energy (AME) and aparent metabolizable energy corrected by nitrogen balance (AME $\mathrm{A}_{\mathrm{n}}$ ) A completely randomized experimental design in a $2 \times 3$ factorial arrangement - two feed forms (crumble and micropellet) and three average particle sizes of the corn $(380,606,806 \mu \mathrm{m})$ - was applied. Three hundred and sixty 1-d-old B.U.T 9 male turkey poults were distributed into 36 cages, 6 replications of 10 birds, each one per treatment. Overall care of birds complied with welfare directive from the Universidade Federal do Paraná. Feed form did not affect the coefficient of total intestinal tract apparent digestibility of $\mathrm{DM}, \mathrm{N}$ or crude fat $(\mathrm{CF})$; however, an increase in corn particle size improved the coefficient of total intestinal tract apparent digestibility of DM, N and CF. AME and $\mathrm{AME}_{\mathrm{n}}$ were not affected by treatments. Feed form does not affect nutrient digestibility on young turkeys and grinding corn at an average particle size bigger than $380 \mu \mathrm{m}$ improves nutrient digestibility.
\end{abstract}

Key Words: fat, metabolizable energy, micropellet, pellet, protein, turkeys

\section{Introduction}

Feed form and average particle size of cereals are factors that deserve attention when manufacturing turkey feed according to the different rearing phases. Particle size reduction is a relatively simple practice and aids the mixing of feedstuffs included in feeds; however, there are practical limits to particle size reduction. Studies reported that birds have difficulty in consuming feed that is excessively larger or smaller than their beak dimension (Moran, 1982; Nir et al., 1994a). The idea that feed particle size reduction increases the surface area of feed contact with digestive enzymes (Jurgens, 1993), thereby improving nutrient digestibility, does not seem to apply to birds (Nir \& Ptchi, 2001). Unlike mammals, birds can compensate their relative short intestine length by reverse peristalsis, where the objective is to re-expose the intestinal digesta to enzymatic secretions in order to optimize digestion (Duke, 1992; Nir et al., 1995). The gizzard is an organ that regulates intestinal transit and is influenced by feed particle size (Nir et al., 1995; Mai, 2007). There is a positive correlation between the average particle size of ingested cereals and gizzard relative weight (Ribeiro et al., 2002; Dahlke et al., 2003; Favero et al., 2009), and studies have shown that feeds produced with coarsely-ground cereal grains increase intestinal transit time and digesta retention in the proximal portion of the gastrointestinal tract (Duke, 1992; Mai, 2007).

Studies of Charbeneau \& Roberson (2004), focusing on phosphorus use in turkey poults reported that total $\mathrm{P}$ and phytate $\mathrm{P}$ retention increased as size increased for corn (606 to $1,094 \mu \mathrm{m})$ and soybean meal (501 to $856 \mu \mathrm{m}$ ), resulting in decreased rickets incidence and contributing to an increase in tibia ash; at $28 \mathrm{~d}$ of age, tibia ash significantly increased $(\mathrm{P}=0.019)$ with coarse corn $(42.3 \%)$ vs. the finest corn (39.4\%). Although average particle size of corn has been frequently investigated with broilers, there is little information on effects of average particle size of feedstuffs for turkeys. This study aimed at evaluating the effect of average particle size of corn in crumbled and micropelleted diets on the coefficient of total intestinal tract apparent digestibility coefficient of total intestinal tract apparent digestibility of dry matter (DM), nitrogen (N), crude fat (CF) and apparent metabolizable energy corrected by nitrogen balance $\left(\mathrm{AME}_{\mathrm{n}}\right)$ by young turkeys. 


\section{Material and Methods}

Three hundred and sixty 1-d-old B.U.T 9 male turkey poults were obtained from a commercial hatchery and previously beak-trimmed. At the arrival at the experimental facilities, poults were individually weighed and distributed into 36 cages, each one measuring $0.90 \mathrm{~m}^{2}$. Temperature was maintained at $32{ }^{\circ} \mathrm{C}$ at placement and was gradually reduced to ensure comfort. Birds were reared under a continuous lighting program reduced to 12 light-hours: 12 days. There were six treatments with six replicates of ten birds each, arranged in a $2 \times 3$ factorial design: two feed forms (crumble and micropellet) and three average particles size of the $\operatorname{corn}(380,606$, or $806 \mu \mathrm{m})$.

Birds were not submitted to any unnecessary discomfort, and directives of the Ethic Committee of the Agrarian Sciences Sector (CEUA - SCA) of the Universidade Federal do Paraná were followed.

Diets were based on corn and soybean meal. The nutritional and digestible amino acid concentration levels were formulated according to the breed manual (Aviagen Turkeys, 2007), (Table 1), and applied to all treatments. Diets were isonutritious, varying only as for feed form and corn particle size. In order to obtain different average particle sizes, corn grains were hammer-milled (Buhler CH-9240) with $1.8,3.0$, and $3.5 \mathrm{~mm}$ diameter sieves. The method described by Zanotto \& Bellaver (1996), was used to numerically characterize corn after milling using sieves. According to the method, $200 \mathrm{~g}$ of the milled sample were oven-dried $\left(105^{\circ} \mathrm{C}, 24\right.$ hours $)$ and fractionated through a series of sieves with different sized openings. The fractions retained on each sieve were quantified by weighing, and their geometric mean diameter (GMD) was calculated using the "SOFTGRAN" software developed by Embrapa Suínos e Aves. The following corn GMDs were 380, 606 and $806 \mu \mathrm{m}$, classified as small, medium, and large; geometric standard deviations (GSD) of 2.07, 1.99, and 1.87, respectively. Soybean meal GMD was $785 \mu \mathrm{m}$ in all treatments.

The pelleting process was performed at $4 \mathrm{~mm}$ pellet diameter (Van Aarsen-C900) and pellets were crumbled in a roller mill resulting in a crumbled diet. The micropelleted diets were made at $1.8 \mathrm{~mm}$ pellet diameter (CPM 2000). At the end of the diet manufacturing process, samples from each treatment were collected and submitted to duplicate analysis to assess the crumbled feed size profile and the physical quality of micropellets. The retention percentage in sieves measuring 1,2, 3 and $4 \mathrm{~mm}$ was used to evaluate the crumbled diets. Pellet durability was expressed as the pellet durability index and was evaluated by the method of the
Table 1 - Composition of basal diets for turkeys at $21 \mathrm{~d}$ of age, $\mathrm{g} / \mathrm{kg}$ as fed

\begin{tabular}{|c|c|}
\hline Ingredient & \\
\hline Soybean meal $46 \%$ & 428.17 \\
\hline Corn grain & 415.00 \\
\hline Corn gluten $60 \%$ & 50.00 \\
\hline Dicalcium phosphate & 27.00 \\
\hline Micronized soybeans & 20.00 \\
\hline Soybean oil & 19.00 \\
\hline Limestone & 14.80 \\
\hline L-Lysine, HCL 78.8\% & 4.20 \\
\hline Methionine analogue, $88 \%{ }^{1}$ & 3.60 \\
\hline Sodium chloride & 2.50 \\
\hline Turkey vitamin and mineral supplement ${ }^{2}$ & 2.50 \\
\hline Sodium bicarbonate & 1.50 \\
\hline L-Threonine $98.5 \%$ & 1.20 \\
\hline Choline chloride $75 \%$ & 0.53 \\
\hline Ferric oxide & 10.00 \\
\hline Total & 1,000 \\
\hline $\begin{array}{l}\text { Calculated nutrients composition, } \% \text { or as } \\
\text { Crude protein }\end{array}$ & 27.18 \\
\hline Crude fat & 4.61 \\
\hline $\mathrm{Ca}$ & 1.29 \\
\hline Available phosphorus & 0.59 \\
\hline $\mathrm{Na}$ & 0.16 \\
\hline AME, $\mathrm{kcal} / \mathrm{kg}$ & 2,950 \\
\hline Digestible arginine & 1.65 \\
\hline Digestible lysine & 1.58 \\
\hline Digestible methionine & 0.65 \\
\hline Digestible methionine + cystine & 1.03 \\
\hline Digestible tryptophan & 0.27 \\
\hline Digestible threonine & 0.99 \\
\hline Digestible valine & 1.12 \\
\hline Digestible isoleucine & 1.04 \\
\hline
\end{tabular}

Table 2 - Retention (\%) in the sieves of crumbled diets, and concentration of fines and pellet durability index (PDI) of micropellets (1.8-mm-diameter die) produced with different corn particle size (GMD, $\mu \mathrm{m})$

\begin{tabular}{lccc}
\hline & \multicolumn{3}{c}{ GMD, $\mu \mathrm{m}$} \\
\cline { 2 - 4 } Feed form & 380 & 606 & 806 \\
\hline Crumbled & & & \\
$4 \mathrm{~mm}$ & 8.7 & 7.7 & 9.5 \\
$3 \mathrm{~mm}$ & 8.0 & 18.2 & 15.4 \\
$2 \mathrm{~mm}$ & 28.9 & 32.5 & 36.8 \\
$1 \mathrm{~mm}$ & 33.9 & 26.1 & 26.3 \\
$0 \mathrm{~mm}^{1}$ & 24.5 & 15.6 & 12.1 \\
Micropelleted & & & \\
Fines, \% & 17.81 & 14.22 & 11.22 \\
PDI & 98.4 & 98.4 & 97.6 \\
\hline 1Bo
\end{tabular}

${ }^{1}$ Bottom plate.

American Society of Agricultural and Biological Engineers (1997); the concentration of fines in the micropelleted feed (Table 2) was also evaluated using the method of the American Society of Agricultural and Biological Engineers (1983). 
A metabolism assay was carried out from 16 to $21 \mathrm{~d}$ of age. The birds were reared until the beggining of the study with the same experimental design and corresponding diet. The method of total excreta collection was applied as described by Sakomura \& Rostagno (2007), using a ferric oxide marker at $1 \%$ to define the beginning and end of the excreta collection period. Metal trays lined with a plastic film were placed under the cages to allow excreta collection, which was collected twice daily (08:00 am and 06:00 pm) and samples were pooled per replicate and immediately frozen $\left(-20^{\circ} \mathrm{C}\right)$. At the end of the assay period, total feed consumed and excreted was determined. Excreta samples were dried in a forced-ventilation oven at $55^{\circ} \mathrm{C}$ for $72 \mathrm{~h}$. Diets and excreta samples were analysed in duplicates for gross energy using an adiabatic bomb calorimeter (IKA - C 2000) and DM, N, and CF according to AOAC International (2000). Based on the results, the coefficients of digestibility were calculated according to the formulas described by Sakomura \& Rostagno (2007).

The data were analysed as a completely randomized design with treatments arranged factorially with feed form, average particle size of the corn and its interaction as main effects, using PROC GLM SAS (Statistical Analysis System, 2001). Individual cages represented the experimental units and the results are presented in tables as mean. All differences were considered significant at $\mathrm{P} \leq 0.05$. When the model was significant, treatment means were separated using the Student-Newman-Keuls test at 5\% level to make pairwise comparisons between sample means.

\section{Results and Discussion}

An interaction between feed form and particle size was observed for the coefficient of total intestinal tract apparent digestibility of $\mathrm{DM}(\mathrm{P} \geq 0.05)$. The feed intake during excreta collection was not affected for the average particle size of the corn ( $\mathrm{P} \geq 0.05$; Figure 1). Feed form did not affect the coefficient of total tract apparent digestibility of any of the traits study ( $\mathrm{P} \geq 0.05$; Table 3 ). The coefficient of total tract apparent digestibility of DM, N, and CF increased as average particle size of the corn increased. Turkeys fed diets with corn ground at an average of $806 \mu \mathrm{m}$ had higher coefficient of total tract apparent digestibility of DM (73.82), N (61.9\%) and CF (92.4\%) than those fed corn ground at $380 \mu \mathrm{m}$ with turkeys fed corn ground at $606 \mu \mathrm{m}$ being intermediates ( $\mathrm{P} \leq 0.05$; Table 3 ). However, the feed form and the increase in average particle size of corn did not affect the AME and $\mathrm{AME}_{\mathrm{n}}$ values $(\mathrm{P} \geq 0.05)$.

Processing temperature can have significant effects on nutrient digestibility. Improvement in the coefficient of

Table 3 - Influence of feed form (FF) and average corn particle size (GMD) on the coefficient of total tract apparent digestibility (CTTAD) of dry matter (DM), nitrogen (N), crude fat (CF), AME and AME $\mathrm{n}_{\mathrm{n}}$ of turkeys of 16 to $21 \mathrm{~d}$ of age

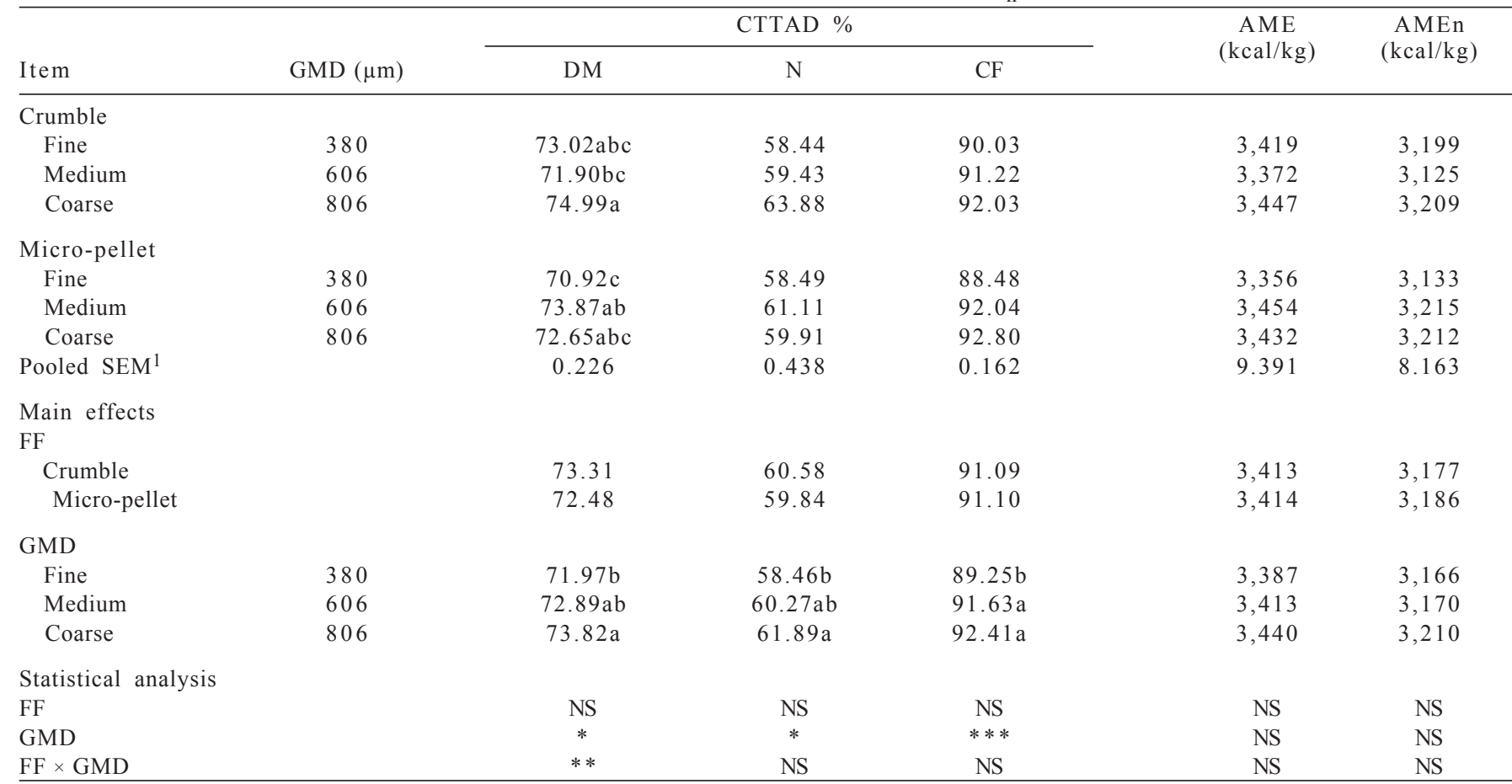

${ }^{1}$ Means represent six pens per diet, 10 birds per pen.

$a-b-c$ Means in the same column not sharing a common letters are different.

NS - not significant $\mathrm{P} \geq 0.05 ; * \mathrm{P} \leq 0.05 ; * * \mathrm{P} \leq 0.01 ; * * * \mathrm{P} \leq 0.001$. 
total tract apparent digestibility of CF and AME of broilers was observed when the diets received a heat treatment (mash and pellet) (López et al., 2007). In our study, due to the pellet mill and speed processes being different between the diets (crumble and micropellet), temperature differed about $10{ }^{\circ} \mathrm{C}$; however, the metabolism assay did not show influence in the coefficient of total tract apparent digestibility of DM, CP, CF, AME and $\mathrm{AME}_{\mathrm{n}}$. Similar reports with broilers did not find improvement in the coefficient of total tract apparent digestibility of DM between mash and pellets diets (Bolton, 1962; Savory, 1975) and of DM, CP, and starch among pellets and expanded pellets diets for growing broilers (Lutch, 2002). According to Amerah et al., (2007), the interaction between feed form and average particle size of corn may be due to changes in feedstuff particle size caused by the pelleting process; however, more studies in this field are necessary. López et al. (2007), evaluating different broiler feed forms (mash, pellets, and expanded pellets) did not find any differences in the coefficient of total tract apparent digestibility of DM, CP and $\mathrm{CF}$ among processed diets; nevertheless, coefficient of total tract apparent digestibility of CP, CF and AME in processed diets were improved in $2.9 \%, 7.5 \%$ and $4.5 \%$, respectively, as compared with birds receiving feed in mash form. According to those authors, coefficient of total tract apparent digestibility of $\mathrm{CP}, \mathrm{CF}$ and AME of processed feeds are improved because the temperature, moisture and pressure processing break the cell walls of grains, which facilitates the access of digestive enzymes to the cell contents (Ortiz et al., 1998).

Data from the current trial agree with those of Krabbe (2000), who observed higher coefficient of total tract apparent digestibility in DM and $\mathrm{N}$ in 0- to 7- day-old

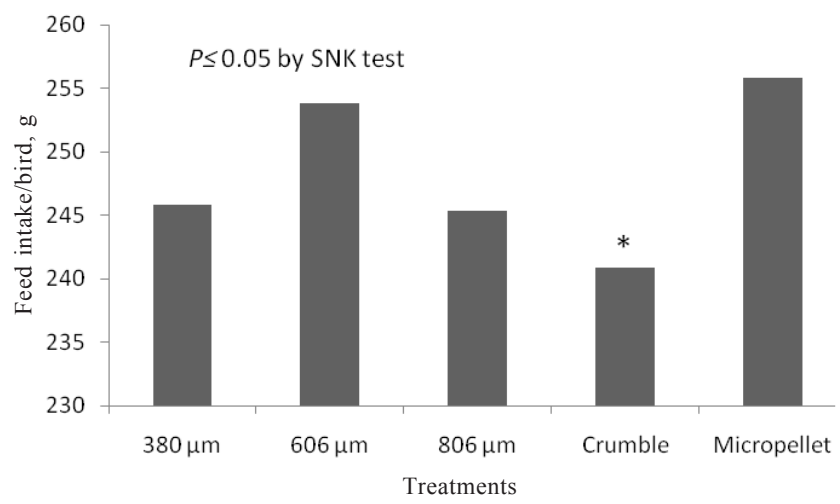

Figure 1 - Turkeys feed intake in dry matter basis during the excreta collection period (16 to $21 \mathrm{~d}$ of age); $\mathrm{SNK}=$ Student-Newman-Keuls. broilers when the average particle size of corn increased from 561 to 763 and $997 \mu \mathrm{m}$. Moreover, these authors found an improvement of $63 \mathrm{kcal}$ of $\mathrm{AME}_{\mathrm{n}} / \mathrm{kg}$ in the feed when the average particle size of corn was increased from 561 to $997 \mu \mathrm{m}$. Parsons et al. (2006), obtained a quadratic AMEn response as size of corn increased in broiler feed form from 781 to $2,242 \mu \mathrm{m}$, obtaining the greatest result with average particle size of $1,042 \mu \mathrm{m}$.

The time available for contact between digested particle and absorptive surfaces are likely to influence the hydrolysis and thus the absorption of nutrients (Mai, 2007). Average particle size tested by Nir et al. (1994b), showed that cereal grains finely ground $(536-574 \mu \mathrm{m})$ resulted in faster passage rate of digesta through the digestive tract of broilers, hindering the action of digestive enzymes and bile salts in the gut. Gastroduodenal reflux in turkeys involves virtually the entire content of the duodenum and upper part of the ileum lumen (Duke, 1992). Studies on gastrointestinal motility using turkeys as an animal model show that the frequency of duodenal reflux in these birds is about 4 times/ hour, whereas in broilers and hens, according to Macari et al. (2002), it may have a lower frequency. This duodenal reflux is related to the particle size of the ingested feed (Duke, 1992). Therefore, it may be hypothesized that the effects on feedstuff average particle size on nutrient retention can be more evident in turkeys due to the difference in duodenal frequency and intensity reflux.

\section{Conclusions}

The physical form (crumble versus micropellet) of the diet does not affect the nutrient digestibility in turkeys at young ages. Grinding corn at an average particle size bigger than $380 \mu \mathrm{m}$ improves nutrient digestibility of dry matter, nitrogen and crude fat in young turkeys.

\section{Acknowledgments}

To the Conselho Nacional de Desenvolvimento Científico e Tecnológico (CNPq) for granting financial support (scholarship) to the first author.

\section{References}

AMERAH, A.M.; RAVINDRAN, V.; LENTLE, R.G. et al. Influence of feed particle size and feed form on the performance, energy utilization, digestive tract development, and digesta parameters of broiler starters. Poultry Science, v.86, p.2615-2623, 2007.

AMERICAN SOCIETY OF AGRICULTURAL AND BIOLOGICAL ENGINEERS. Cubes, pellets and crumbles. Definitions and 
methods for determining density, durability, and moisture. St. Joseph, MI: American Society of Agricultural and Biological Engeneers, 1997. 5p. (Publication S269.4).

AMERICAN SOCIETY OF AGRICULTURAL AND BIOLOGICAL ENGINEERS. Methods of determining and expressing fineness of feed materials by sieving. St. Joseph, MI: American Society of Agricultural and Biological Engeneers, 1983. 3p. (Publication, S319).

ASSOCIATION OF OFFICIAL ANALYTICAL CHEMISTRY AOAC. Official methods of analysis. 17.ed. Gaithersburg, MD: AOAC International, 2000. 173p.

AVIAGEN TURKEYS. B.U.T. Commercial Turkeys management guide. West Virginia, USA: Aviagen Turkeys Inc., 2007. 36p.

BOLTON, W. The digestibilty of mash and pellets by chicks. Journal of Agricultural Science, v.55, p.141-142, 1962.

CHARBENEAU, R.A.; ROBERSON, K.D. Effect of corn and soybean meal particle size on phosphorus use in turkey poults. Journal of Applied Poultry Research, v.13, p.302-310, 2004.

DAHLKE, F.A.; RIBEIRO, A.M.L.; KESSLER, A.M. et al. Effects of corn particle size and physical form of the diet on the gastrointestinal structures of broiler chickens. Brazilian Journal of Poultry Science, v.5, p.61-67, 2003.

DUKE, G.E. Recent studies on regulation of gastric motility in turkeys. Poultry Science, v.81, p.1-8, 1992.

FAVERO, A.; MAIORKA, A.; DAHLKE, F. et al. Influence of feed form and corn particle size on the live performance and digestive tract development of turkeys. Journal of Applied Poultry Research, v.18, p.772-779, 2009.

JURGENS, M.H. Methods of feedstuff preparation. In: Animal Feeding and Nutrition. 7.ed. Dubuque, IA: Kendall/Hunt Publ. Co., 1993. p.220-225.

KRABBE, E.L. Níveis de sódio, tamanho de partícula da dieta e peso do pinto à eclosão e o desempenho na fase préinicial (1 a 7 dias). 2000. 146f. Tese (Doutorado em Zootecnia). Universidade Federal do Rio Grande do Sul, Porto Alegre.

LÓPEZ, C.A.A.; BAIÃO, N.C.; LARA, L.J.C. et al. Efeitos da forma física da ração sobre a digestibilidade dos nutrientes e desempenho de frangos de corte. Arquivo Brasileiro de Medicina Veterinária e Zootecnia, v.59, n.4, p.1006-1013, 2007.

LUTCH, W.H. Mejoramiento de la producción de pollo por médio de la expansion de alimento. Industria Avicola, v.50, p.32-35, 2002.

MACARI, M.; FURLAN, R.L.; GONZALES, E. Fisiologia aviária aplicada a frangos de corte. Jaboticabal: Funep, 2002. 375p.
MAI, A.K. Wet and coarse diets in broiler nutrition: Development of the GI tract and performance. 2007. $141 \mathrm{f}$. Thesis (PhD in Animal Sciences) - Institute of Animal Sciences/ Wageningen University and Research Centre, Wageningen, Netherlands.

MORAN, E.T. Comparative nutrition of fowl and swine: the gastrointestinal systems. Office of Educational Practice. Ontario, CA: University of Guelph, 1982. 253p.

NIR, I.; SHEFET, G.; ARONI, Y. Effect of particle size on performance. 1. Corn. Poultry Science, v.73, p.45-49, 1994a.

NIR, I.; HILLEL, R.; SHEFET G. et al. Effect of grain particle size on performance. 2. Grain texture interaction. Poultry Science, v.73, p.781-791, 1994b.

NIR, I.; HILLEL, R.; PTCHI, I. et al. Effect of particle size on performance. 3.Grinding pelleting interactions. Poultry Science, v.74, p.771-783, 1995 .

NIR, I.; PTICHI, I. Feed particle size and hardness: Influence on performance, nutritional, behavioural and metabolic aspects. In: WORLD FEED CONFERENCE, 1., 2001, Utrecht, the Netherlands. Proceedings... Wageningen, the Netherlands: Wageningen Press, 2001. p.157-186.

ORTIZ, L.T.; REBOLE, A.; RODRGUEZ, E. et al. Effect of chicken age on the nutritive value of diets with graded additions of fullfat sunflower seed. British. Poultry Science, v.39, p.530-535, 1998.

PARSONS, A.S.; BUCHANAN, N.P.; BLEMINGS, K.P. et al. Effect of corn particle size and pellet texture on broiler performance in the growing phase. Journal of Applied Poultry Research, v. 15 , p. $245-255,2006$.

RIBEIRO, A.M.L.; MAGRO, N.; PENZ, A.M.Jr. Corn particle size on broiler grower diets and its effect on performance and metabolism. Brazilian Journal of Poultry Science, v.4, p.1-7, 2002.

SAKOMURA, N.K.; ROSTAGNO, H.S. Métodos de pesquisa em nutrição de monogástricos. Jaboticabal: Funep, 2007. 283p.

SAVORY, C.J. Growth and behaviour of chicks on pellets or mash. British. Poultry Science, v.15, p.281-286, 1975.

STATISTICAL ANALYSIS SYSTEM INSTITUTE - SAS. User's guide statistics. Cary, 2001. 155p.

ZANOTTO, D.L.; BELlaVER, C. Método de determinação da granulometria de ingredientes para uso de rações de suínos e aves. Concórdia: Embrapa Aves e Suínos, 1996. 5p. (Documentos, 215). 